\title{
M. Lesley Wilkins (1944-2007)
}

July 2007 was a crucl month for the many who had the privilege of knowing Lesley Wilkins, who died at the age of 62 on July 23 . A warm, generous, smart, and disarmingly offbeat woman, Lesley was a consummate professional, tireless guide, and highly respected authority in her field of Middle Eastern librarianship. Beyond the commitment and conscientiousness that defined her professional life, however, bcyond her signature courtesy and the consideration she extended to all and sundry, Lesley was foremost a beloved friend to countless, who deeply mourn her passing.

At the moment of her death lesley was the Bibliographer for Law of the Islamic World at Harvard Law School Library, an inaugural position that she held just shy of ten years. Her indefatigable efforts transformed the inchoate collection that she inherited into a major resource both within and outside Harvard.

Lesley studied English and French at Simmons College for her B.A., received her library degree from the University of Southern California in Los Angeles, and earned an M.A. in Middle East Area Studies from the American University of Beirut. Eighteen years later she became a Ph.D. candidate at Harvard. Fitting her studies into her life as time and career permitted, her research into early Egyptian documents was close to completion upon her death; the title of her thesis, bits of which she presented at a number of conferences on Arabic papyrology, was "From Papyrus to Paper: Technology Transfer in Medieval Egyptian Society."

Lesley began her professional experience as the Young Adult Librarian at Los Angeles Public Library, moving from there in 1972 to Harvard College Library as Middle Eastern Cataloguer and then Assistant Middle East Librarian. She interrupted her Harvard career in 1977 with a two-year stint in Austin as head of the Middle East Collection of the University of 'Texas General Library system, ten years at the Boston Public Library - which included a two-year lcave in the mid-1980s as Deputy Director of the Sultan Qaboos University library, in Muscat, Oman - and six years at the American University in Cairo Library, where she was first head of the Rare Books and Special Collections Library and University Archives and later Associate Dircctor. From Cairo lesley returned to Harvard in 1997 to build and manage the collection of Islamic law and positive law of the Islamic world at Harvard Law School.

At Harvard lesley spearheaded the expansion of the Islamic law collection, but her expertise and leadership extended far beyond the library stacks. She was involved in the activities of Harvard Law School's Islamic Legal Studies Program, attending many of its events, preparing bibliographies in support of its symposia, and curating book exhibits on the theme of its conferences from the Library's increasingly rich collection. She played a major role in developing with the Library of Congress its long-awaited classification system for Islamic Law (KBP). She provided advice and guidance in the establishment of the Library of the Harvard Medical School Dubai Center Institute for Postgraduate Education and Research. She took part in a Simmons and Harvard delegation that went to Amman, Jordan, to lay the groundwork in setting up courses for Iraqi librarians to catch up with developments in the profession they had missed in the past two decades. She was preparing a distance-learning course on Middle Eastern librarianship that she would teach in the fall of 2008. The list of her achievements in library outreach is too long to enumerate. 
In addition Lesley was diligent about her professional responsibilities, sitting on many committees in many professional societies, from the American Library Association to the Art Libraries Society of North America to the Middle East Librarians Association, of which she was President from 2003-2005.

Lesley's abiding love, in addition to her husband Peter Wilkins, her son Alex Dukas, and her families at home and across the Atlantic, was travel. When she found out that she need have no illusions about longevity, she began crossing off places and continents she had yet to visit. Her trip to Australia and New Zealand was memorable, as was the fulfillment of her long-standing desire to visit Antarctica. Had there been a mosque, or better, a library with a Middle Eastern collection on Antarctica, Lesley would have gone out of her way to stop in. Her thoughts, even in her very last days, were always with her profession, as now we think of her in all that we do and are thankful for the time we were given to share in this wonderful woman's life.

Peri Bearman

Harvard law Scbool 